\title{
Primary volcanic structures from a type section of Deccan Trap flows around Narsingpur-Harrai-Amarwara, central India: Implications for cooling history
}

\author{
Piyali Sengupta* and Arijit Ray \\ Department of Geology, Presidency College, 86/1 College Street, Kolkata 700 073, India. \\ *e-mail: piysen@yahoo.co.in
}

Field investigations of the Deccan Trap lava sequence along a $70 \mathrm{~km}$ traverse in the NarsingpurHarrai-Amarwara area of central India indicate twenty lava flows comprising a total thickness of around $480 \mathrm{~m}$. Primary volcanic structures like vesicles and cooling joints are conspicuous in this volcanic succession and are used to divide individual flows into three well-defined zones namely the lower colonnade zone, entablature zone, and the upper colonnade zone. The variable nature of these structural zones is used for identification and correlation of lava flows in the field. For twenty lava flows, the thicknesses of upper colonnade zones of eight flows are $\sim 5 \mathrm{~m}$ while those of eight other flows are $\sim 8 \mathrm{~m}$ each. The thicknesses of upper colonnade zones of remaining four flows could not be measured in the field. Using the thicknesses of these upper colonnade zones and standard temperature-flow thickness-cooling time profiles for lava pile, the total cooling time of these sixteen Deccan Trap lava flows has been estimated at 12 to 15 years.

\section{Introduction}

Deccan volcanism, representing a tremendous outburst of volcanic activity, marks an important episode in Indian geological history, affecting nearly two-thirds of peninsular India. The Deccan volcanic province is one of the most important and largest flood basalt provinces of the world. It has attracted the attention of geologists because it coincided with the Cretaceous-Tertiary boundary $\sim 65$ million years ago (Duncan and Pyle 1988; Courtillot et al 1988; Venkatesan et al 1993; Baksi 1994). The Deccan Trap lava pile is the thickest in the western part of the province reaching an exposed thickness of about $1.7 \mathrm{~km}$ in parts of the Western Ghats (Sen 2001) - this region is considered as an important eruption centre. A second region of lava extrusion has been considered to be the Narmada-Satpura-Tapi of central India (Crookshank 1936; Sen and Cohen 1994; Bhattacharji et al 1994; Sheth 2000; Ray et al 2006). Many studies of Deccan basalts have covered the southwestern part of the province (Mahoney et al 1982; Cox and Hawkesworth 1984, 1985; Lightfoot and Hawkesworth 1988; Peng et al 1994; Bondre et al 2006). In comparison, the eastern part of the Deccan province has been little studied (Crookshank 1936; Alexander and Paul 1977; Yedekar et al 1996; Deshmukh et al 1996; Pattanayak and Srivastava 1999). Both the southwestern and eastern parts of the Deccan volcanic province contain several well-exposed lava flow sections where primary volcanic structures of lava flows can be used for flow identification and correlation. It has been indicated by earlier geologists that individual flows can often be traced for long distances (e.g., West 1959). Primary volcanic structures provide one of the most useful criteria for identification of lava flows in the field and their correlation (Tomkeieff 1940; Wentworth and Macdonald 1953; Waters 1961; Swanson 1967; Macdonald 1967; Long and Wood

Keywords. Deccan Traps; lava flows; volcanism; isotherm; cooling history. 
1986). Among primary volcanic structures, some structures like vesicles are formed due to the escape of gas from the lava flows during the initial cooling of the basaltic flows, while others like columnar or other types of jointing are developed during solidification.

Structures of flood basalts have been described from Hawaiian region (Stearns and Macdonald 1946; Wentworth and Macdonald 1953; Macdonald 1953, 1956, 1967; Walker 1971, 1987; Hon et al 1994; Kauahikaua et al 1998), Ireland (Tomkeiff 1940) and the Columbia River Plateau (Waters 1960, 1961; Swanson 1967; Long and Wood 1986; Self et al 1996; Reidel 1998) and several other areas. De $(1972,1974)$ emphasized the importance of volcanic structures in describing and correlating different flows of the Deccan Traps. He utilized a three-tier classification consisting of five structural zones which includes:

- Upper vesicular zone grading into upper colonnade zone;

- Entablature zone;

- Lower colonnade zone grading into lower vesicular zone.

De (1996) also identified different patterns of jointing (chevron pattern, fanning columns, inclined columns, rosettes, etc.) in the entablature zone in the Deccan Trap flows of the Satpura region and discussed the nature, origin and usefulness of these zones. Recently Bondre et al (2000, 2004), Duraiswami et al (2001, 2002) and Sheth (2006) have documented the morphology and emplacement of flows from the Deccan Volcanic Province and compared them with those from other provinces.

It has been found (De 1996) that the thickness of different structural zones in a flow have a direct relationship with the cooling history of the lava. The cooling and crystallization of Makaopuhi crater lava lake (Wright and Okamura 1977) and Alae lava lake (Peck 1978) in Hawaii were observed in detail and it was found that there is a relation between depth of the lava lake and elapsed time (Peck 1978). It is interesting that the thicknesses of Alae $(\sim 15 \mathrm{~m})$ and Makaopuhi $(84 \mathrm{~m})$ lava lakes compare well with the thicknesses of the common Deccan Trap flows, particularly those in the Satpuras. Using this observation, the cooling time of individual flows and the total cooling time of an entire lava sequence can be calculated from individual flow thicknesses.

The area of the present research forms an important section as it exposes a large number of flows in the eastern part of the Satpura area. This work presents a detailed description of primary volcanic structures in these Deccan Trap flows and presents a stratigraphic succession of lava flows around the Narsingpur-Harrai-Amarwara area of central India. Efforts have also been made to understand the cooling history and cooling time of these lava flows.

\section{Geological setting}

The investigated area lies in the eastern part of Satpuras in Madhya Pradesh to the south of Narmada river in between latitudes $22^{\circ} 20^{\prime}$ and $22^{\circ} 50^{\prime} \mathrm{N}$ and longitude $79^{\circ} 10^{\prime}$ and $79^{\circ} 20^{\prime} \mathrm{E}$. The area is mostly covered by dense jungle with several rivers and nullahs. The area is hilly south of Narsingpur. Detailed mapping was undertaken along the NarsingpurHarrai-Amarwara road section. The major rock types within the area are Deccan Trap basaltic flows which overlie the Upper Gondwana sediments of Triassic-Jurassic age (Crookshank 1936; Dixey 1970; Pattanayak and Srivastava 1999). The Deccan Traps in this area consist of horizontal 'simple' lava flows (Walker 1971; Deshmukh 1988; De 1996). The Gondwana rocks are mainly exposed in the northern parts of the investigated area in between Narsingpur and the village Jaitpur (figure 1B) and mainly consist of conglomerates, white-coloured massive sandstone and buff coloured sandstone.

\section{Lava stratigraphy}

Twenty simple lava flows (Walker 1971) have been identified in the study area forming a nearly $480 \mathrm{~m}$ thick sequence from $405 \mathrm{~m}$ at the base to $885 \mathrm{~m}$ at the top. A traverse was made along a N-S trending road connecting Narsingpur with Amarwara town (figure 1B), which cuts across the topography and intersects the different contours exposing different flows at different heights. This main road section and some associated other nullah sections and well sections around the road form the important sites of exposures that have helped in flow identification and construction of stratigraphic succession.

\subsection{Identification of lava flows}

Twenty flows have been identified and correlated in the field in the study area on the basis of primary volcanic structures. Each and every flow is characterized by some distinctive structural features. A three-tier classification of primary volcanic structures (De 1972, 1974, 1996) can be utilized here for flow identification and correlation. This includes the lower colonnade zone overlain by the entablature zone and the upper colonnade zone. The three-tier classification scheme (De 1972, 1974) of structures of Deccan basalts was adopted originally 


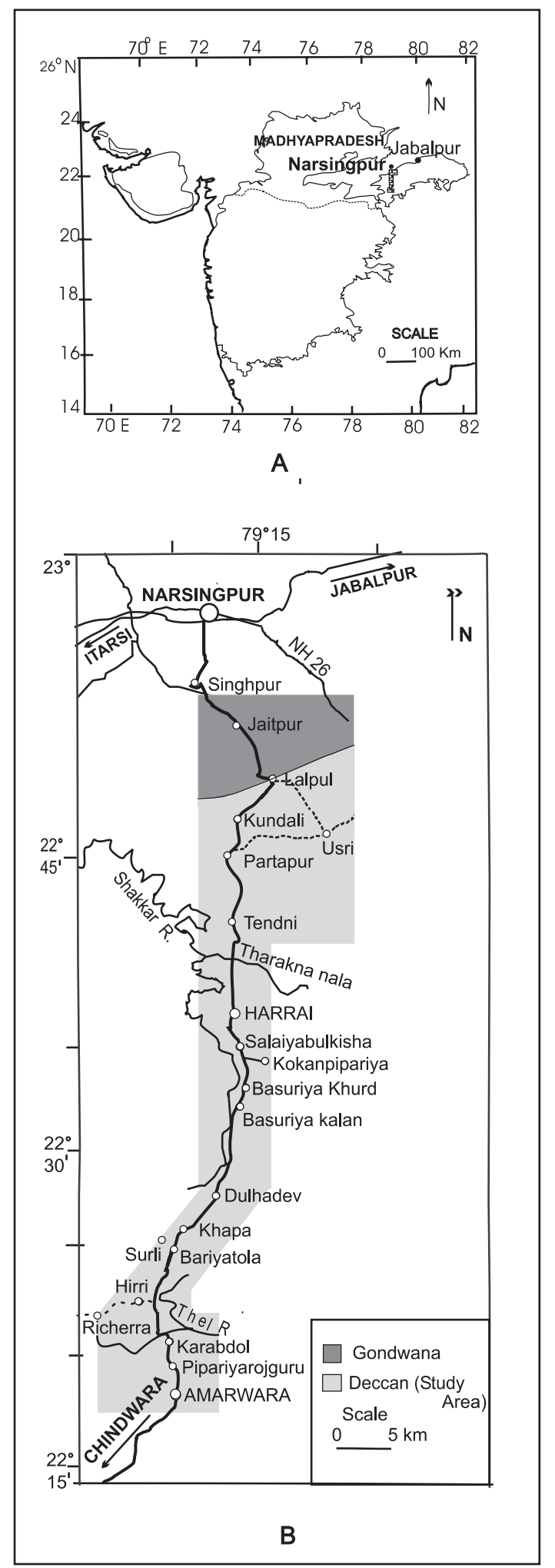

Figure 1. (A) Map of India showing location of the study area. (B) Map showing important towns, villages, rivers and nullahs in and around the study area.

from Tomkeieff (1940) and Spry (1962). The terms lower colonnade zone, entablature zone and the upper colonnade zone were originally proposed by Tomkeieff (1940). He noted a well-developed lower colonnade zone followed by the entablature zone, which has a variety of structures, such as curvicolumnar structure. According to Tomkeieff (1940) the top part of a basalt flow is characterized by the presence of a pseudo-columnar zone. Spry (1962) found that this zone is marked commonly by columnar jointing resulting in colonnade structure and hence he termed this zone as the upper colonnade zone.

The lower colonnade zone of a single lava flow in the investigated area is characterized by welldeveloped columns in the lower part of the flow, including the vesicular part at the lower contact. The upper part is characterized by less well-formed columnar jointing forming the upper colonnade zone, which merges with the upper vesicular part. In between the lower and the upper colonnade zones, there is a central zone with more irregular jointing, which is called the entablature zone. In this entablature zone upright columns are absent or very slender and give rise to a variety of patterns, such as chevron, fanning out either upwards or downwards. Variations of this entablature zone from flow-to-flow serve as an excellent criteria for the identification of individual lavas, as also previously observed by De (1972) in southern Kachchh.

The upper part of the upper colonnade and lower part of lower colonnade zones typically have numerous closely spaced vesicles. These zones are known as upper vesicular zone and lower vesicular zone, respectively. The nature and size of vesicles help to distinguish different flows in some cases. It has been observed that upper and lower vesicular zones of most of the flows are characterized by black soil intermixed with weathered chips of basalts, which are highly glassy in nature. The nature of vesicles can be studied in few cases where the upper part of the upper colonnade zone or lower part of the lower colonnade zone becomes highly vesicular and forms the upper vesicular zone or the lower vesicular zone, i.e., the case where the columnar joints can still be discerned within the vesicular zone. For example, the upper part $(2-3 \mathrm{~m})$ of the upper colonnade zone of flow III shows numerous large circular vesicles $(2-5 \mathrm{~mm}$ in diameter) filled up by calcite and hence this part of the upper colonnade zone can be called the upper vesicular zone. In some cases (e.g., flow II, IX) the upper vesicular zone (ranging in thickness from 1-5 m) consists of black soil with small boulders (varying in size from $4-7 \mathrm{~cm}$ long and $4-6 \mathrm{~cm}$ wide) of highly weathered vesicular/amygdaloidal basalts. In all the cases, the frequency of vesicle distribution appears to be high throughout the whole lower and upper vesicular zones leading to the formation of black soil with weathered basalt chips. 
Table 1. The number of different flows as observed at different villages within the study area.

\begin{tabular}{ll}
\hline Location name & $\begin{array}{c}\text { Flow numbers } \\
\text { exposed }\end{array}$ \\
\hline Lalpul & I \\
Kundali & II, III, IV \\
Usri & I, II \\
Partapur & V, VI, VII \\
Tendni & VII \\
Harrai & VIII, IX \\
Salaiyabulkisha & VIII, IX \\
Kokanpipariya & X, XI \\
Basuriya Khurd & XI, XII, XIII \\
Basuriya Kalan & IX, X \\
Dulhadev & XVI, XVII \\
Khapa & XVIII, XIX \\
Bariyatola & XIX, XX \\
Surli & XVIII \\
Hirri & XVII \\
Richerra & XVIII \\
Karabdol & XIV, XV \\
Pipariyarojguru & XVII, XVIII \\
Amarwara & XVI, XVII \\
\hline
\end{tabular}

All the specimens of Deccan Trap flows of the study area are grey-coloured, fine-grained porphyritic rocks. Phenocrysts vary in size generally from $3 \mathrm{~mm}$ to $1 \mathrm{~cm}$. Few larger plagioclase phenocrysts $(\sim 6-7 \mathrm{~mm})$ were observed in parts of some flows but no flow was characterized by some particular phenocrystic character which can be used as an independent means of correlation, like the Roza member of CRBG (Hooper 1997).

Under the microscope, all the basaltic flows are characterized by development of phenocryst phases like olivine (both fresh and pseudomorphed by iddingsite and chlorite), pyroxene and plagioclase, whereas the groundmass is represented by tiny grains of olivine, plagioclase, pyroxene, opaque and interstitial glass. Petrographic studies indicate that the rocks of entablature zone of a flow have a larger amount of modal glass content than in the rocks of adjacent lower and upper colonnade zones, and in many cases a smaller grain size has also been observed. These two features indicate that the entablature zone had formed by an event of quenching of the crystallizing basaltic melt. The lower glass content in the modes of rocks from the two colonnade zones are indicative of their more gradual cooling.

\subsection{Erection of volcanic stratigraphic column}

The stratigraphic succession of the present area has been constructed by correlating different local stratigraphic columns. The thicknesses of different flows have been assessed from the thicknesses of different structural zones. As the flows are all horizontal, the position of a particular flow in the stratigraphic column has been determined with the help of its total thickness and contour heights. The number of different flows as observed in each location of figure 1(B) has been shown in the following table 1 . The stratigraphic succession of the area is shown in figure $2(\mathrm{~A})$.

\section{Volcanic structures in lava flows}

It has been observed that the Deccan Trap flows of the Narsingpur-Harrai-Amarwara area show well-developed lower colonnade zones, entablature zones and upper colonnade zones characterized by distinctive features of columns which are very well exposed in most of the cases and as a result can be used for flow identification and correlation. Some of the flows are characterized by huge lower or upper colonnade zones while some show the variable nature of entablature zone like fanning columns, intersecting, inclined columns, etc. Flow I is characterized by huge $(1.5-1.8 \mathrm{~m})$ black columns in the lower colonnade zone. Flow XV shows wide hexagonal columns in the lower colonnade zone (figure 3 ). Flow XVI shows a 6 -m thick entablature zone containing two sets of intersecting joints (figure 4). Slender columns of upper colonnade zone of flow XV (figure 5) have been observed in a well section in north of the village Karobdol (figure 1B). Flow XVI is characterized by a 7-m thick upper colonnade zone with spectacular development of slender columns (figure 6) exposed near the village Dulhadev (figure 1B). Lower or upper vesicular zones also characterize a few flows showing the variable nature of shape, size, distribution of vesicles; e.g., flow III shows closely spaced large circular vesicles $(2-5 \mathrm{~mm}$ in diameter $)$ filled up by calcite in the upper vesicular zone which is very useful for flow identification and correlation. A detailed description of salient features of different structural zones of all the Deccan Trap flows of the study area is shown in table 2. A schematic diagram showing the salient structural features of all the different flows as has been described in table 2 is shown in figure 2(A). Sketches of primary volcanic structures of some flows are shown in figure $2(\mathrm{~B})$.

\section{Discussion on cooling history}

It has been found that the thicknesses of different zones in a flow are directly related to the cooling history of that lava (De 1996). Wright and Okamura (1977) investigated the cooling and crystallization of an $84 \mathrm{~m}$ deep and $365 \mathrm{~m}$ wide lava 




I,II,III,IV.......denotes flow numbers

1 Vertical columnar joints

이 Columns showing spheroidal weathering

El Columns with prominent horizontal joints

Fragmented entablature zone

$\mathbb{V}$ Entablature zone with haphazardly oriented columns

Entablature zone with two sets of intersecting joints

Black soil

Black soil

Black soil

Black soil

Black soil
Slender columns showing spheroidal weathering in the upper colonnade zone

Huge columns in the lower colonnade zone

Thin entablature zone showing irregular columns

Columns showing spheroidal weathering in the upper colonnade zone

columns in the lower colonnade zone

Vesicular upper part of the upper colonnade zone

Fragmented entablature zone

Wide columns in the lower colonnade zone

Thick upper colonnade zone

Thick entablature zone showing fanning columns

Columns with block joints in the lower colonnade zone

Slender columns with fine vesicles in the upper part

Well exposed columns, wider in upper part of the lower colonnade zone

Long slender columns in the upper colonnade zone

Wide columns in the lower colonnade zone

Black soil with amygdules

Thick zone of black soil (Highly weathered flow)

Columns with closely spaced horizontal joints

Slender columns in the upper colonnade zone

Fragmented entablature zone

Slender columns in the upper colonnade zone

Black soil with few basalt fragments

Spheroidally weathered slender columns in the upper colonnade zone

Huge columns with coarse vesicles in the upper part of the Lower colonnade zone

Columns with prominenent horizontal joints in the upper colonnade zone

Black soil with small basalt fragments

Irregular columns in the entablature zone

Thick lower colonnade zone

Spheroidal weathering in the upper colonnade zone

Well developed wide columns in the lower colonnade zone

Wide columns with horizontal joints in the upper colonnade zone

Columns with large vesicles in the upper colonnade zone

Black soil with small basalt fragments

Huge columns in the upper colonnade zone showing spheroidal

Highly fragmented entablature zone weathering

Wide columns in the upper colonnade zone

Very wide columns in the lower colonnade zone

\begin{tabular}{lll|}
\hline \multirow{2}{*}{ SCALE: } & Height : & $\underline{10 \mathrm{~m}}$ \\
& width of columns: & $\overline{1 \mathrm{~m}}$ \\
\hline
\end{tabular}

$\mathbb{W}$ Entablature zone with fanning columns

Vesicular zones containing mixture of black soil, basaltic

\%: Large vesicles/amygdules fragments and amygdules

Black soil

Figure 2. (A) Schematic diagram showing the salient features of primary volcanic structures of twenty Deccan Trap basaltic lava flows in Narsingpur-Harrai-Amarwara area of Madhya Pradesh. 


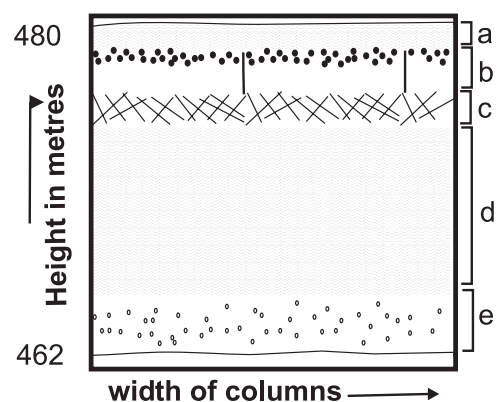

(i)



(iii)

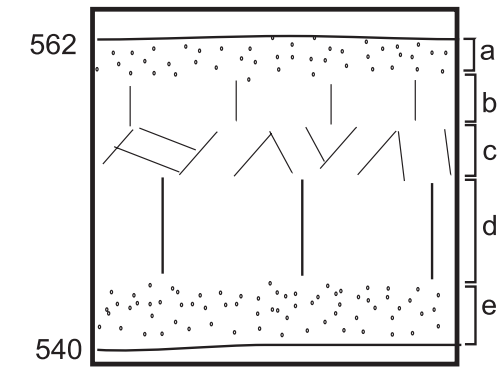

(ii)

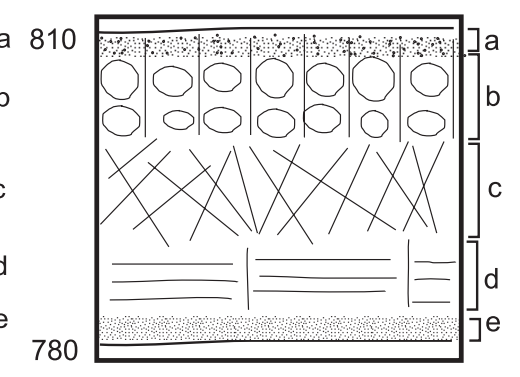

(iv)

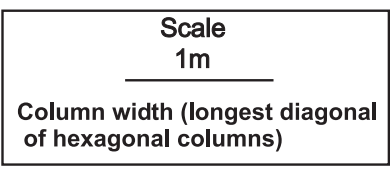

Figure 2. (B) Sketches showing structural details of some flows as shown in figure 2(A). (i) Flow II exposed in south of Kundali; (ii) Flow VII as exposed in Tendni; (iii) Flow XIII as exposed in Basuriya Khurd; (iv) Flow XVII as exposed in Dulhadev. (a) upper vesicular zone; (b) upper colonnade zone; (c) entablature zone; (d) lower colonnade zone; (e) lower vesicular zone. Explanations of symbols are the same as figure 2(A).

lake, the Makaopuhi lava lake, which formed during the eruption of Makaopuhi lava lake (Kilauea volcano, Hawaii) in 1965 and they found a relation between the depth of the lava pond and elapsed time. They determined the temperature at different dates in drill holes. It was observed that during cooling and crystallization of the lava lake, isotherms in the partly solidified crust formed in the upper part migrated downward in the lake, as a linear function of square root of elapsed time $(\sqrt{ } t)$. Thus the isotherms show a sloping nature from the top surface of the lava lake downwards which is consistent with heat loss mainly from the top.

Later Peck (1978) investigated another stagnant lava lake, the Alae lava lake, formed during a Kilaeuea eruption in 1963. The lake was $15 \mathrm{~m}$ deep and $260-310 \mathrm{~m}$ in diameter. Temperatures in Alae lava lake during the 4 years when it solidified and cooled below $100^{\circ} \mathrm{C}$ are summarized in figure 7 . It can be observed from this figure that during the early stages of cooling and crystallization of the lava lake, isotherms in the partly solidified crust formed in the upper part, migrated downward in the lake as a linear function of square root of elapsed time $(\sqrt{ } t)$. This behaviour indicates that the lava cooled mainly by conduction of heat. The initial slope of isotherms was disturbed largely as a result of rainfall. The sloping nature of the isotherms from the top surface of the lava lake downwards is consistent with heat loss mainly from above. In later stages of cooling, the downward sloping linear nature of the isotherms is disturbed and finally shows a reversal of direction (figure 7) as they join the isotherms which are moving inwards from the base of the lava flow (Peck et al 1966). The gradual slope of the isotherms from top and bottom surface of the lake (the latter with a steeper slope) may be interpreted as the requirement for the formation of vertical columnar jointing, where a particular isotherm gradually penetrates deeper with time. Worster et al (1993) showed that cooling by conduction to the country rock below, in addition to cooling at the upper surface results in solidification of a lava lake from the roof, as well as from the base. This cooling should occur in response to the two sets of isotherms, one set sloping downwards from the top, another inclined upwards from the bottom. Curvature of isotherms in the middle part appears to be a result of heat loss into the floor rocks.

The study area, which falls in the eastern part of the Satpura, shows different basaltic flows of 


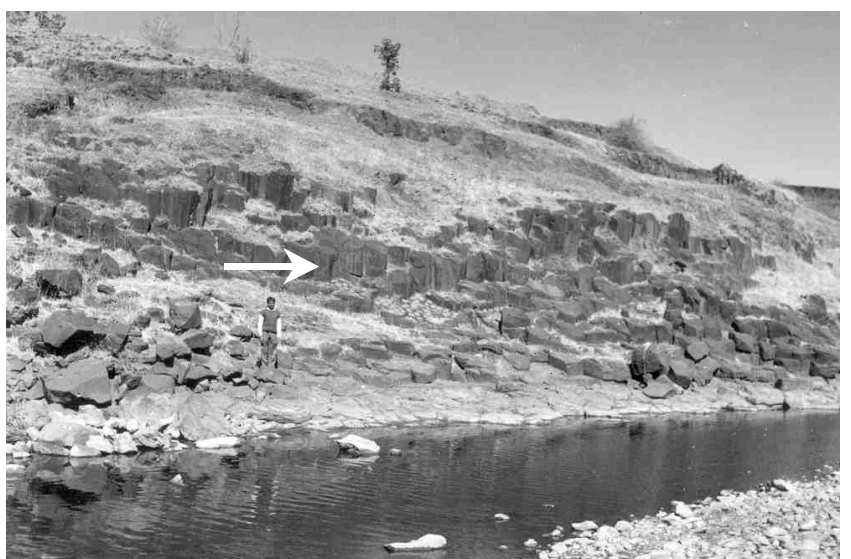

Figure 3. Wide hexagonal columns (marked by an arrow) in the lower colonnade zone of flow XV in the Thel River, due north of the village Karobdol.



Figure 4. Two sets of prominent intersecting joints (marked by a black and a white arrow) in the entablature zone of the flow XVI, exposed in the road cutting near the village Dulhadev.

variable thicknesses. Utilizing the diagram of Peck (1978), we have attempted to infer the cooling time of different lava flows from the measured thicknesses of different structural zones of different flows.

The variation of isotherms in temp-depth-time graph (figure 7) is very distinct up to a maximum depth of $8 \mathrm{~m}$ from the top surface of the lava lake. So, this cooling model can be applied for the upper part of a lava flow, i.e., the upper colonnade zone of a flow up to a maximum thickness of $8 \mathrm{~m}$. In our area, the upper colonnade zones of twenty basaltic flows can be subdivided into two categories based on their thickness: (a) upper colonnade zones of different flows showing a thickness around $5 \mathrm{~m}$ (flows IV, V, VI, VIII, IX, XI, XIII and XIV); (b) upper colonnade zones of different flows showing a thickness around $8 \mathrm{~m}$ (flows I, II, X, XIV, XVI, XVII, XVIII and XIX). Considering the fact that the Deccan basalts have crystallized at

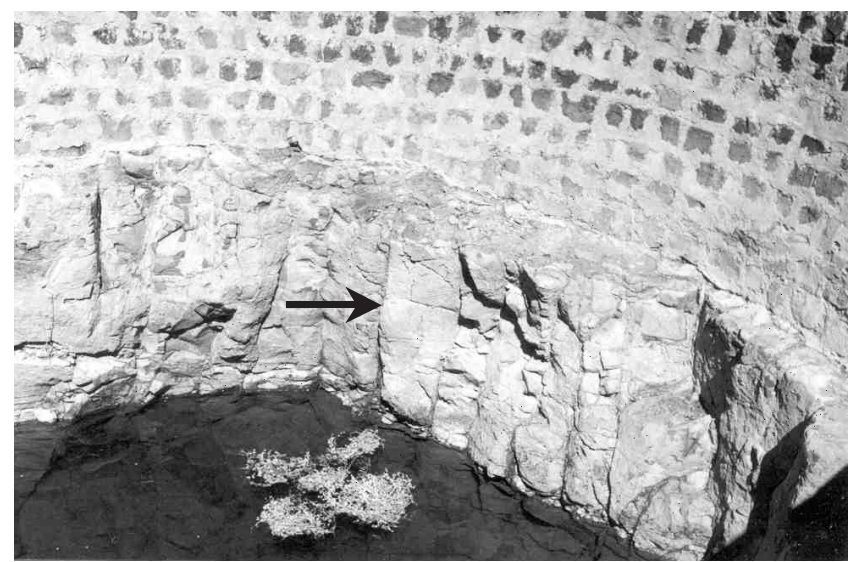

Figure 5. Slender columns (marked by an arrow) in the upper colonnade zone of flow XV within a well-section in the north of the village Karobdol.

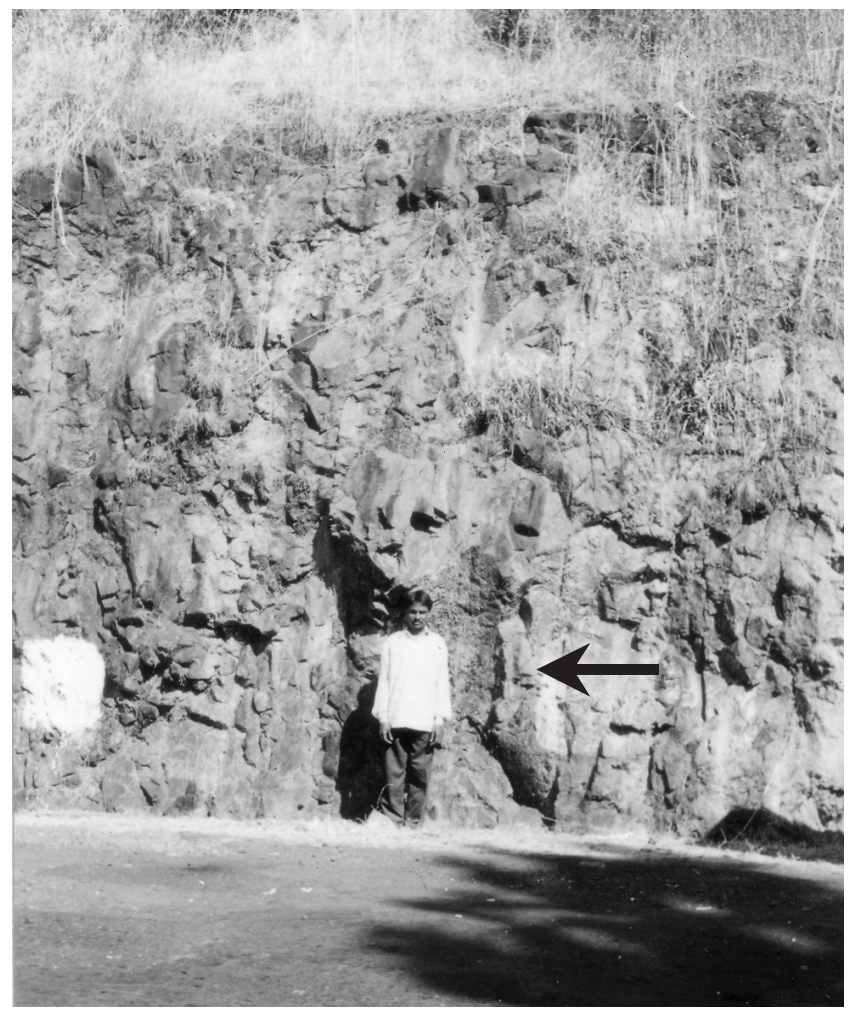

Figure 6. Spectacular development of slender columns (marked by an arrow) in the upper colonnade zone of flow XVI, exposed below $780 \mathrm{~m}$, south of the village Dulhadev.

temperatures of $900^{\circ} \mathrm{C}$ and $1000^{\circ} \mathrm{C}($ De 1996), the cooling time of different basaltic flows can be determined from slopes of $900^{\circ} \mathrm{C}$ and $1000^{\circ} \mathrm{C}$ isotherms and thicknesses of upper colonnade zones of different flows. We found that the cooling time of the twenty different basaltic flows of the present area fall into two different categories; flows with thinner upper colonnade zones ( $\sim 5 \mathrm{~m}$ thick) have solidified in between 196 days and 225 days whereas flows 


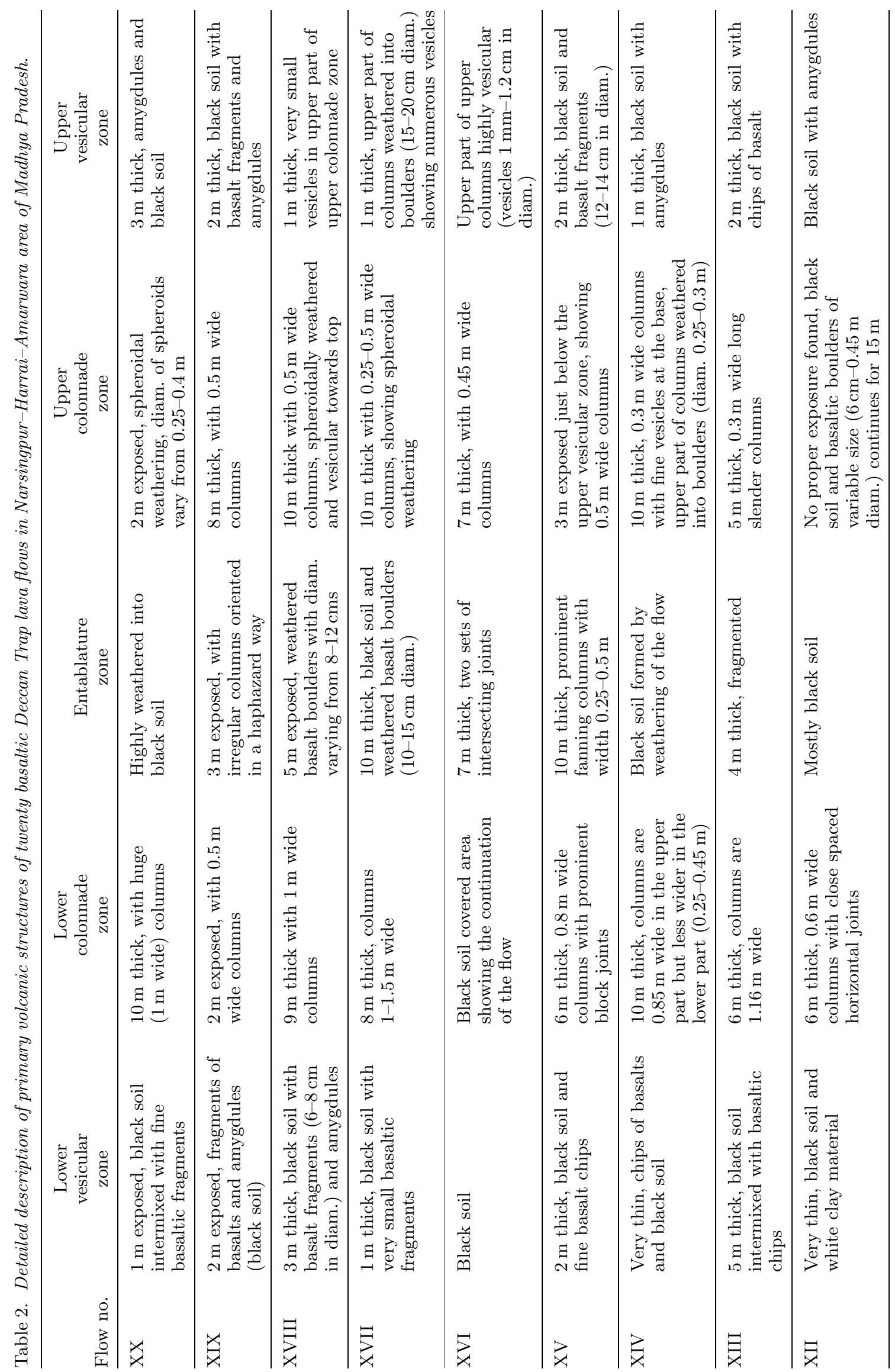




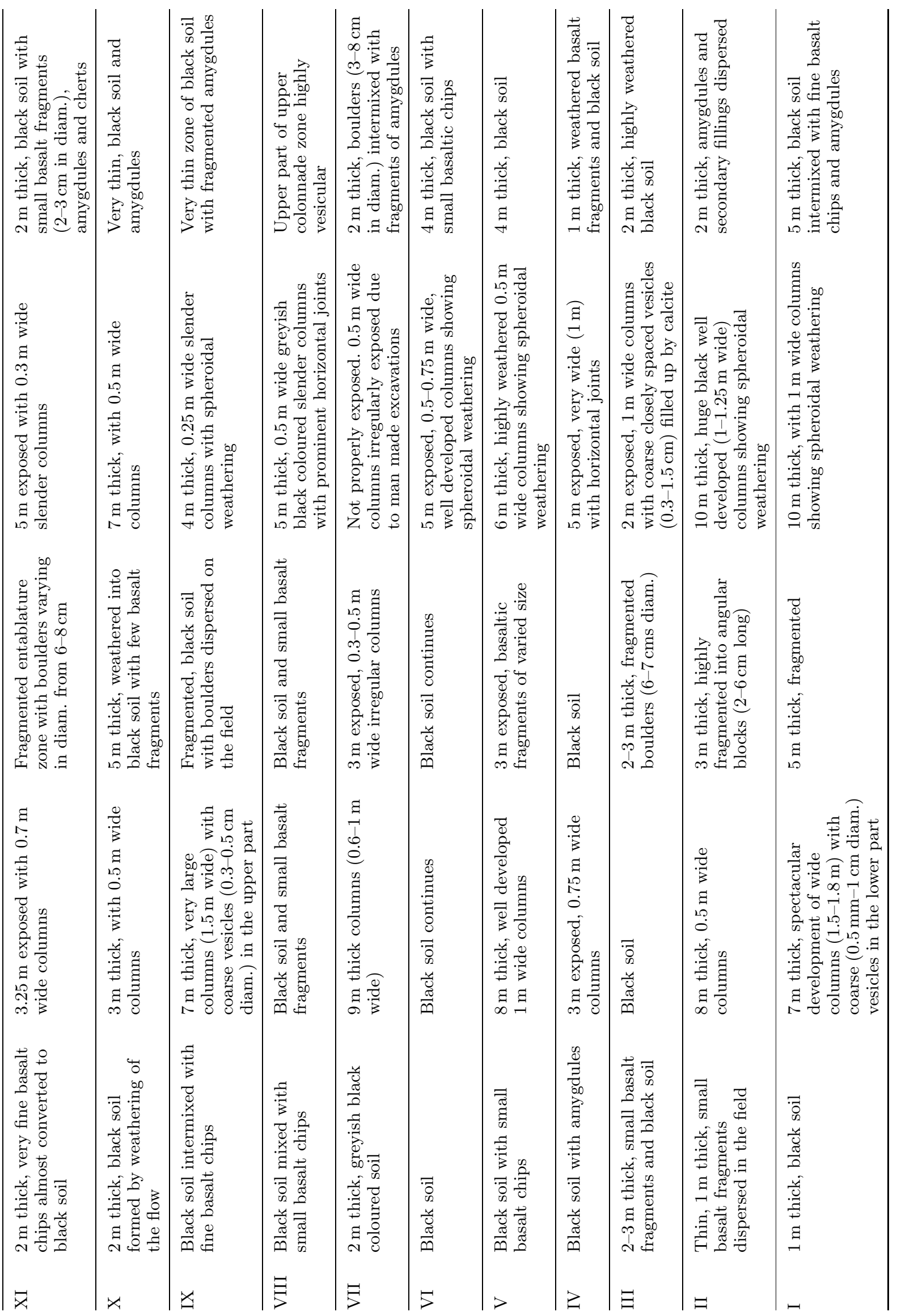




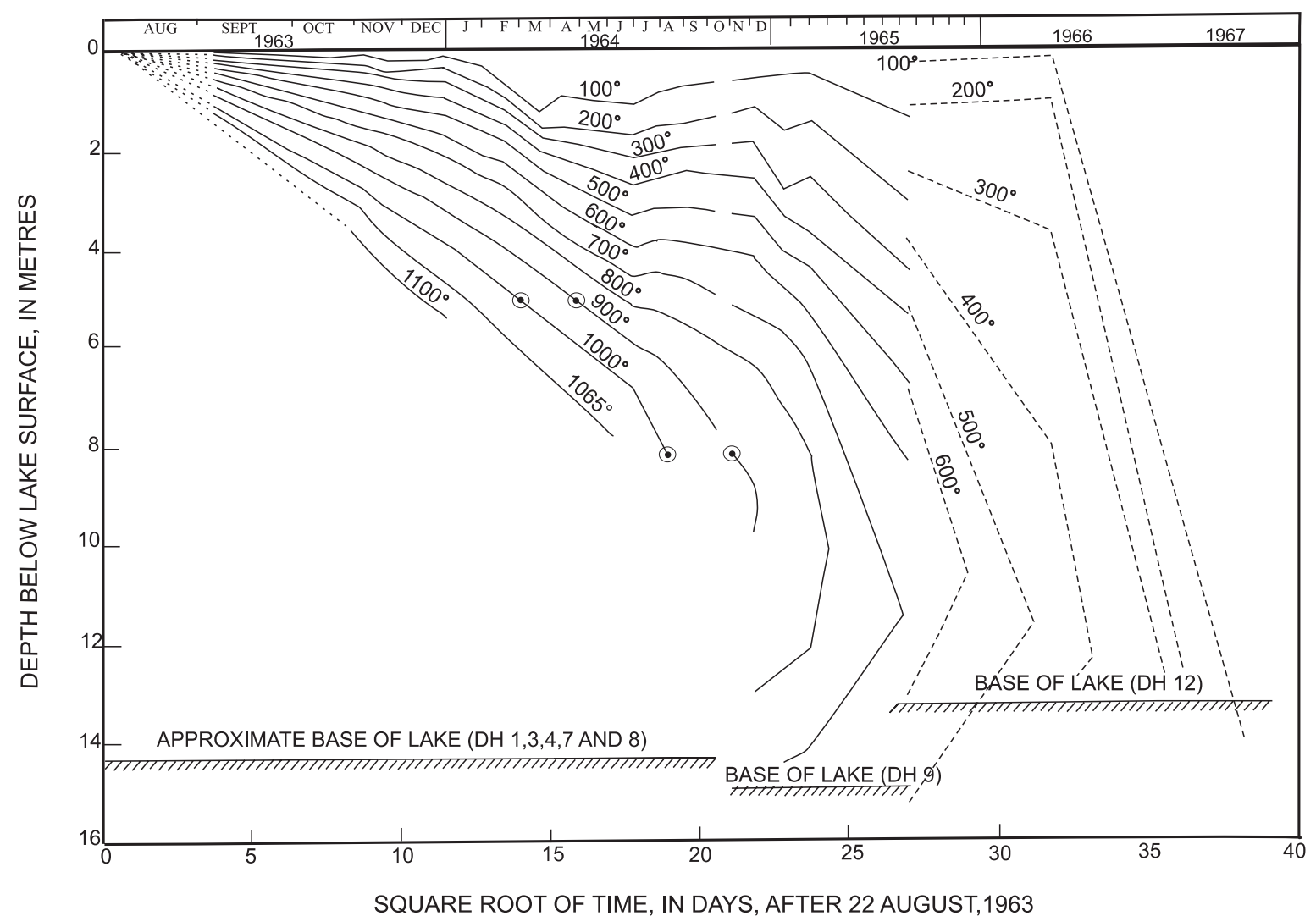

Figure 7. Depth of isotherms (in degree centigrade) in Alae lava lake of Hawaii from August 22, 1963 to August 1967 as a function of the square root of time $\sqrt{ } t$ (days). DH $1,3 \ldots$ indicate different drillhole numbers (Diagram after Peck 1978). Centered circles represent data of average thicknesses of upper colonnade zones of the Deccan flows of the study area.

with thicker upper colonnade zones $(\sim 8 \mathrm{~m}$ thick $)$ have solidified in 361 days to 441 days. In the total sequence of twenty basaltic lava flows, the total cooling time of the 8 flows with a thinner upper colonnade zone approximately varied in between 4 years and 4 months and 4 years and 11 months, whereas the total cooling time of 8 flows with thicker upper colonnade zone varied in between 7 years and 11 months and 9 years and 8 months. The remaining four flows do not have any proper exposures of upper colonnade zones. Assuming that the one flow came as soon as the previous one was solidified, the total cooling time of the volcanic sequence consisting of 16 flows including both the categories of thinner and thicker upper colonnade zones varies in between 12 years 3 months and 14 years 7 months. The actual cooling time of the whole basaltic volcanic sequence consisting of 20 lava flows would have been slightly higher than this calculated time as it involved four more flows. As it has been observed (figure 7) that the pattern of isotherms in the lower part of the lake are much steeper than the upper part, it is likely that the rate of cooling of lava is slower in the upper part than the lower part. Thus the cooling time of the upper colonnade zone might represent the cooling time of the whole flow because in most of the cases the thickness of the lower colonnade zone is more or less similar or less than the thickness of the upper colonnade zone. Exceptions are flows VII, IX and $\mathrm{X}$ where lower colonnade zones are much thicker than the upper colonnade zones and in these cases it is very difficult to predict the cooling time of the whole flow until and unless we get the total picture of the pattern of isotherms for the lower part of the flow.

\section{Conclusions}

Primary volcanic structures are considered very efficient tools for identification and correlation of lava flows in the field. The present study area in the eastern part of the Satpura region exposes twenty basaltic flows, which have been identified and correlated in the field with the help of primary volcanic structures. The stratigraphy of the area has also been constructed with the knowledge of the thickness of different flows and contour heights. The cooling history and the approximate cooling time of the different lava flows and the cooling time of the whole volcanic sequence have been estimated 
from the temp-depth-time graph of Peck (1978) at 12 to 15 years (average $\sim 13.5$ years).

\section{Acknowledgements}

Piyali Sengupta records her deep sense of gratitude to late Prof. Aniruddha De of Calcutta University who taught the author the art of studying primary volcanic structures in Deccan Trap Basalts. She also thanks her brother Sri Dipayan Sengupta for his help during the fieldwork. The authors thank Dr. Stephen Reidel, Dr. Raymond A Duraiswami and Dr. Ninad Bondre for their critical and careful reviews. The authors also thank Dr. Hetu Sheth for his thoughtful comments. The authors are grateful to the Department of Science and Technology, New Delhi for financial support. The authors are also thankful to the Head of the Department of Geology, Presidency College, Kolkata, for providing infrastructural facilities during the work.

\section{References}

Alexander P O and Paul D K 1977 Geochemistry and Sr isotopic composition of basalts from eastern Deccan basaltic province, India; Min. Mag. 41 165-172.

Baksi A J 1994 Geochronological studies on whole-rock basalts, Deccan Traps, India: evaluation of the timing of volcanism relative to the $\mathrm{K}-\mathrm{T}$ boundary; Earth. Planet. Sci. Lett. 121 43-56.

Bhattacharji S, Chatterjee N, Wampler J M and Gazi M 1994 Mafic dikes in Deccan volcanics-indicator of India intraplate rifting, crustal extension and Deccan flood basalt volcanism; In: Volcanism (ed.) Subbarao K V (Wiley Eastern), pp. 253-276.

Bondre N R, Duraiswami R A, Dole G, Phadnis V M and Kale V S 2000 Inflated pahoehoe lavas from Sangamner area of the western Deccan Volcanic Province; Curr. Sci. 78 1004-1007.

Bondre N R, Duraiswami R A, Dole G 2004 Morphology and emplacement of flows from the Deccan Volcanic Province, India; Bull. Volcanol. 66 29-45.

Bondre N R, Hart W K and Sheth H C 2006 Geology and geochemistry of the Sangamner mafic dike swarm, Western Deccan Volcanic Province, India: Implications for regional stratigraphy; J. Geol. 114 155-170.

Cox K G and Hawkesworth C J 1984 Relative contribution of crust and mantle to flood basalt magmatism, Mahabaleshwar area, Deccan Traps; Phil. Trans. Roy. Soc. London A 310 627-641.

Cox K G and Hawkesworth C J 1985 Geochemical stratigraphy of the Deccan Traps at Mahabaleshwar, Western Ghats, India, with implications for open system magmatic processes; J. Petrol. 26 355-377.

Crookshank H 1936 The Geology of the northern slopes of the Satpuras between the Morand and Sher rivers; Geol. Surv. India Memoir 66(2) 218.

Courtillot V, Feraud H, Maluski D, Moreau M G and Besse J 1988 Deccan flood basalts and the Cretaceous/Tertiary boundary; Nature 333 843-846.
De A 1972 Structural features of the Deccan Trap tholeiites basalt flows of southern Kutch; Proc. Indian Sci. Cong., 56th Sess. Pt. III, p. 180.

De A 1974 Short and long distance correlation of the Deccan Trap lava flows (abs.); Bull. Geol. Min. Met. Soc. India 4750.

De A 1996 Entablature structure in Deccan Trap flows: Its nature and probable mode of origin; Gond. Geol. Mag. 2 439-447.

Deshmukh S S 1988 Petrographic variations in compound flows of Deccan Traps and their significance; In: Deccan flood basalts (ed.) Subbarao K V, Geol. Soc. India Memoir $10305-319$

Deshmukh S S, Sano T and Nair K K K 1996 Geology and chemical stratigraphy of the Deccan basalts of Chikaldara and Behramghat sections of the eastern part of the Deccan Trap province, India; Gond. Geol. Mag. 2 1-22.

Dixey F 1970 The geomorphology of Madhya Pradesh; In: West Commemoration volume, pp. 195-224.

Duncan R A and Pyle D G 1988 Rapid eruption of the Deccan flood basalts at the Cretaceous/Tertiary boundary; Nature 333 841-843.

Duraiswami R A, Bondre N R, Dole G, Phadnis V M and Kale V S 2001 Tumuli and associated features from the western Deccan volcanic province, India; Bull. Volcanol. 63 435-442.

Duraiswami R A, Bondre N and Dole G 2002 Morphology and structure of flow-lobe tumuli from Pune and Dhule areas, western Deccan Volcanic Province; J. Geol. Soc. India 60 57-65.

Hon K, Kauahikaua J, Denlinger R and Mackay K 1994 Emplacement and inflation of pahoehoe sheet flows: observations and measurements of active lava flows on Kilauea Volcano, Hawaii; Geol. Soc. Am. Bull. 106 351-370.

Hooper P R 1997 The Columbia River Flood Basalt Province: current status; In: Large Igneous Provinces: Continental, Oceanic, and Planetary Flood Volcanism (eds) Mahoney J J and Coffin M F (Washington, Amer. Geophys. Union), Geophys. Monogr. 100 1-27.

Kauahikaua J, Cashman K V, Heliker C, Hon K A, Mangan M T, Mattox T N and Thornber C R 1998 Observations on basaltic lava streams in tubes from Kilauea Volcanic island of Hawaii; J. Geophys. Res. 103 $27,303-27,323$.

Lightfoot P C and Hawkesworth C J 1988 Origin of Deccan Trap lavas: evidence from combined trace element and Sr-, Nd- and Pb-isotopic studies; Earth. Planet. Sci. Lett. $9189-104$.

Long P E and Wood B J 1986 Structures, textures and cooling histories of Columbia River basalt flows; Geol. Soc. Am. Bull. 97 1144-1155.

Macdonald G A 1953 Pahohoe, aa, and Block Lava; Amer. J. Sci. 251 169-191.

Macdonald G A 1956 The structure of Hawaiian volcanoes; Koening. Nederlandsch Geol. Mijnb. Genotschap. $16274-295$.

Macdonald G A 1967 Forms and Structures of Extrusive Basaltic Rocks; In: Basalts: The Poldervaart Treatise on Rocks of Basaltic Composition (eds) Hess $\mathrm{H} \mathrm{H}$ and Poldervaart A (New York, Interscience Publ.), pp. 1-61.

Mahoney J J, Macdougall J D, Lugmair G W, Gopalon K and Krishnamurthy P 1982 Origin of the Deccan Trap flows at Mahabaleshwar inferred from $\mathrm{Nd}$ and $\mathrm{Sr}$ isotopic and chemical evidence; Earth. Planet. Sci. Lett. 60 47-60.

Pattanayak S K and Srivastava J P 1999 Petrography and major-oxide geochemistry of basalts from the eastern 
Deccan basalt province; In: Deccan Volcanic Province (ed.) Subbarao K V, Geol. Soc. India Memoir 43 233-270.

Peck D L 1978 Cooling and vesiculation of Alae lava lake, Hawaii; U.S. Geol. Surv. Prof. Pap. 935-B 1-50.

Peck D L, Wright T L and Moore J 1966 Crystallization of tholeiitic basalt in Alae lava lake, Hawaii; Bull. Volcanol. 29 629-656.

Peng Z X, Mahoney J J, Hooper P R, Harris C and Beane J 1994 A role for lower continental crust in flood basalt genesis? Isotopic and incompatible element study of the lower six formations of the western Deccan Traps; Geochem. Cosmochim. Acta. 57 5109-5130.

Ray R, Sheth H C and Mallik J 2006 Structure and emplacement of the Nandurbar-Dhule mafic dyke swarm, Deccan Traps, and the tectonomagmatic evolution of flood basalts; Bull. Volcanol. (in press).

Reidel S P 1998 Emplacement of Columbia River flood basalt; J. Geophys. Res. 103 27,393-27,410.

Self S, Thordarson T, Keszthelyi L, Walker G P L, Hon K, Murphy M T, Long P and Finnemore S 1996 A new model for the emplacement of Columbia River basalts as large, inflated pahoehoe lava flow fields; Geophys. Res. Lett. 23 2689-2692.

Sen G 2001 Generation of Deccan Trap magmas; Proc. Indian Acad. Sci. (Earth. Planet. Sci.) 110(4) 409-431.

Sen G and Cohen T H 1994 Deccan intrusion, crustal extension, doming and the size of the Deccan -Reunion plume head; In: Volcanism (ed.) Subbarao K V, Geol. Soc. India 201-216.

Sheth H C 2000 The timing of crustal extension, diking, and eruption of the Deccan flood basalts; Int. Geol. Rev. 42 $1007-1016$.

Sheth H C 2006 The emplacement of pahoehoe lavas on Kilauea and in the Deccan Traps; J. Earth Syst. Sci. (in revision).

Spry A 1962 The origin of columnar jointing, particularly in basalt flows; J. Geol. Soc. Australia 8 191-216.
Stearns H T and Macdonald G A 1946 Geology and ground water resources of the Island of Hawaii; Hawaii Div. Hydrography Bull. 9363.

Swanson D A 1967 Yakima Basalt of the Tieton River area, South-Central Washington; Bull. Geol. Soc. Amer. 78 1077-1110.

Tomkeieff S I 1940 The basalt lavas of the Giant's Causeway district of Northern Ireland; Bull. Volcanol. Ser. 2, 6 89-143.

Venkatesan T R, Pande K and Gopalon G 1993 Did Deccan volcanism predate the Cretaceous/Tertiary transition?; Earth. Planet. Sci. Lett. 119 181-189.

Walker G P L 1971 Compound and simple lava flows and flood basalts; Bull. Volcanol. 35 579-590.

Walker G P L 1987 Pipe vesicles in Hawaiian basalt lavas: their origin and potential as paleoslope indicators; Geology 15 84-87.

Waters A C 1960 Determining direction of flow in basalts; Amer. J. Sci., Bradley Vol. 258-A 350-366.

Waters A C 1961 Stratigraphic and lithological variations in Columbia River Basalt; Amer. J. Sci. 259 583-611.

Wentworth C K and Macdonald G C 1953 Structure and forms of basaltic rocks in Hawaii; U.S. Geol. Surv. Bull. 99498.

West W D 1959 The Source of the Deccan Trap flows; J. Geol. Soc. India 1 44-52.

Worster M G, Huppert H E and Sparks R S J 1993 The crystallization of lava lakes; J. Geophys. Res. 98 $15,891-15,901$.

Wright T L and Okamura R T 1977 Cooling and crystallization of tholeiitic basalt 1965 Makaopuhi lava lake, Hawaii; U.S. Geol. Surv. Prof. Pap. 1004.

Yedekar D B, Aramaki S, Fujii T and Sano T 1996 Geochemical signature and stratigraphy of the ChhindwaraMandla sector of the eastern Deccan volcanic province and problems of its correlation; Gond. Geol. Mag. Spl v. 2 49-68. 